Pendas : Jurnal IImiah Pendidikan Dasar, ISSN Cetak : 2477-2143 ISSN Online : 2548-6950

Volume III Nomor 1, Juni 2018

\title{
PENINGKATAN HASIL BELAJAR SISWA DENGAN MENGGUNAAKAN MODEL PEMBELAJARAN PICTURE AND PICTURE PADA PEMBELAJARAN \\ PPKn DALAM MATERI MAKNA PERSATUAN DAN KESATUAN DALAM KEBERAGAMAN SISWA KELAS TINGGI SDN PAHLAWAN
}

\author{
Asep Deni Normansyah \\ PPKn FKIP Universitas Pasundan \\ Alamat e-mail : asepdeninormansyah@unpas.ac.id
}

\begin{abstract}
The research used is Classroom Action Research which used consist of 2 cycles and through 4 stages. The purpose of this learning outcome is to know the improvement of student learning outcomes by using the model of Picture and Picture learning on learning PPKn in the material meaning of unity and unity in the diversity of high school students (IV) SDN Pahlawan Sub District Banjaran Bandung. After using the model of Picture and Picture learning in the learning of $P P K n$, the students' learning motivation is more improved, more active and more focused in learning. This research uses Picture and Picture method. The results of this study indicate that with learning Picture and Picture on PPKn subjects can improve student learning outcomes. Looking at the results of the pre-cycle evaluation with the average grade value of 67. In cycle 1 grade average grade 71.67, cycle 2 grade average value of 83.67 has a significant increase. Based on the results of the research, there is an increase in student learning outcomes by using Picture and Picture learning model on learning PPKn in the material meaning of unity and unity in the diversity of high school students (IV) SDN Pahlawan Banjaran District, Bandung Regency can improve student learning outcomes.
\end{abstract}

Keywords: Picture and picture learning model, learning result, Meaning of Unity and Unity in Diversity.

\begin{abstract}
ABSTRAK
Penelitian yang digunakan adalah Penelitian Tindakan Kelas yang dipakai terdiri dari 2 siklus dan melalui 4 tahapan. Tujuan hasil pembelajaran ini adalah untuk mengetahui peningkatan hasil belajar siswa dengan menggunakan model pembelajaran Picture and Picture pada pembelajaran PPKn dalam materi makna persatuan dan kesatuan dalam keberagaman siswa kelas tinggi (IV) SDN
\end{abstract}


Pahlawan Kecamatan Banjaran Kabupaten Bandung. Setelah menggunakan model pembelajaran Picture and Picture dalam pembelajaran PPKn maka motivasi belajar siswa lebih meningkat, lebih aktif dan lebih fokus dalam pembelajaran. Penelitian ini menggunakan metode Picture and Picture. Hasil penelitian ini menunjukkan bahwa dengan pembelajaran Picture and Picture pada mata pelajaran PPKn dapat meningkatkan hasil belajar siswa. Melihat hasil evaluasi pra siklus dengan nilai rata-rata kelas sebesar 67. Pada siklus 1 nilai rata-rata kelas 71,67, siklus 2 nilai rata-rata kelas sebesar 83,67 mengalami peningkatan yang signifikan. Berdasarkan hasil penelitian yang diperoleh maka terdapat peningkatan hasil belajar siswa dengan menggunakan model pembelajaran Picture and Picture pada pembelajaran PPKn dalam materi makna persatuan dan kesatuan dalam keberagaman siswa kelas tinggi (IV) SDN Pahlawan Kecamatan Banjaran Kabupaten Bandung dapat meningkatkan hasil belajar siswa.

Kata Kunci : Model pembelajaran Picture and picture, hasil belajar, Makna Persatuan dan Kesatuan dalam Keberagaman.

\section{A. Pendahuluan}

Pada umumnya anak (siswa) cenderung belajar lebih banyak melibatkan seluruh inderanya, sajian model apapun asal itu melibatkan panca indera. Pada saat mereka mencapai usia dewasa, lebih suka gaya belajar menggunakan gambar visual ternyata lebih dominan. Hal ini berarti bahwa pesan yang kita sampaikan kepada siswa lebih banyak diserap lewat indera mata. Dari sini dapat kita simpulkan bahwa penggunaan model pembelajaran Picture and Picture dalam proses pembelajaran perlu diupayakan adanya, agar pesan yang guru sampaikan dapat secara efektif diterima oleh siswa sebagai penerimaan pesan dari guru.

Pembelajaran terpusat pada guru masih menemukan beberapa kelemahan. Kelemahan tersebut dapat dilihat pada saat berlangsungnya proses pembelajaran di kelas, interaksi aktif antara siswa dengan guru atau siswa dengan siswa jarang terjadi. Siswa kurang terampil menjawab pertanyaan atau bertanya tentang konsep yang diajarkan. Siswa kurang bisa bekerja dalam kelompok diskusi dan pemecahan masalah yang diberikan. Mereka cenderung belajar sendirisendiri. Pengetahuan yang didapat bukan dibangun sendiri secara bertahap oleh siswa atas dasar 
pemahaman sendiri. Karena siswa jarang menemukan jawaban atas permasalahan atau konsep yang dipelajari.

Cara penyampaian materi oleh guru kepada siswa kurang menyenangakan dan masih menggunakan metode pembelajaran yang konvesional yang terus menerus sehingga mengakibatkan siswa pasif dan pembelajaran yang membosankan. Setelah dilakukan evaluasi terhadap hasil belajar ternyata dengan pendekatan pembelajaran seperti itu hasil belajar siswa dirasa belum maksimal. Hal ini tampak pada pencapaian nilai akhir. Dalam satu tahun belakangan ini siswa yang memperoleh nilai ratarata kelas 67. Rendahnya pencapaian nilai akhir siswa tersebut, menjadi indikasi bahwa pembelajaran yang dilakukan selama ini belum efektif. Nilai akhir dari evaluasi belajar belum mencakup penampilan dan partisipasi siswa dalam pembelajaran hingga sulit untuk mengukur keterampilan siswa.Untuk memperbaiki hal tersebut perlu kiranya disusun suatu model dalam pembelajaran yang lebih kooperatif yang dapat mengaitkan materi teori dengan kenyataan yang ada di lingkungan sekitarnya. Atas dasar itulah peneliti mencoba mengembangkan model kooperatif dalam pembelajaran dengan model Picture and Picture.

Model pembelajaran adalah kerangka konseptual yang melukiskan prosedur yang sistematis dalam mengorganisasikan pengalaman belajar peserta didik untuk mencapai tujuan belajar tertentu, dan berfungsi sebagai pedoman bagi perancang pembelajaran guru dalam merencanakan dan melaksanakan aktifitas belajar mengajar (Syaiful sagala, 2005).

Salah satu model pembelajaran tersebut di antaranya adalah model Picture and Picture yang menggunakan gambar-gambar. Dalam proses pembelajarannya siswa dirangsang dengan gambar dan warna yang menarik bahkan bila perlu ditambah dengan media audio visual untuk lebih menambah ketertarikan sehingga dengan demikian siswa diharapkan dapat memperoleh pengalaman belajar baik dan tujuan dari kompetensi tercapai secara kognitif, afektif dan psikomotor. 
Media visual (image atau perumpamaan) memegang peran sangat penting dalam proses belajar. Media visual dapat memperlancar pemahaman dan memperkuat ingatan. Visual dapat pula menumbuhkan minat siswa dan dapat memberikan hubungan antara isi materi dengan dunia nyata. Bentuk Visual bisa berupa : (a) gambar resperensi seperti gambar, lukisan atau foto yang menunjukkan bagaimana tampaknya sesuatu benda; (b) diagram yang melukiskan hubungan-hubungan konsep, organisasi, dan struktur isi materi; (c) Peta yang menunjukkan hubunganhubungan ruang antara unsur-unsur dalam isi materi; (d) grafik seperti tabel, grafik, dan chart (bagan) yang meyajikan gambaran/kecenderungan data atau hubungan seperangkat gambar atau angka-angka (Azhar, 91-92:2007).

Menurut Suprijono (2010:110) model Picture and Picture adalah suatu metode pembelajaran yang menggunakan gambar dan dipasangkan atau diurutkan menjadi urutan logis. Dalam hal ini guru menyampaikan kompetensi yang ingin dicapai, manyampaikan materi sebagai pengantar. Setelah itu guru menunjukkan atau memperlihatkan gambar-gambar yang berkaitan dengan materi. Siswa tidak hanya mendengar dan membuat catatan, guru memanggil siswa secara bergantian memasang atau mengurutkan gambar-gambar menjadi urutan yang logis. Ditanyakan juga alasan atau dasar pemikiran urutan gambar tersebut. Dari alasan atau urutan gambar, guru memulai menanamkan konsep atau materi sesuai dengan kompetensi yang ingin dicapai. Dengan demikian diharapkan hasil belajar siswa pada mata pelajaran PPKn yang menggunakan model pembelajaran Picture and Picture dapat meningkatkan hasil belajar siswa dan dapat dijadikan sebagai upaya pembaharuan dalam paradigma pembelajaran.

Berdasarkan pengamatan sementara peneliti di SDN Pahlawan Kecamatan Banjaran Kabupaten Bandung tepatnya di kelas tinggi, menurut pendapat saya sendiri pada kenyataannya proses pembelajarannya hanya dilakukan dengan metode konvensional yang cenderung monoton dan kurang mampu menggali potensi yang ada pada siswa. Peran guru cenderung 
lebih aktif dibandingkan siswa, hal ini tentu berpengaruh terhadap pemahaman siswa dan hasil belajar siswa yang terlihat masih banyak yang dibawah nilai rata-rata kelas.

\section{B. Landasan Teori (Huruf 12 dan} Ditebalkan)

Pada bagian ini uraikan secara singkat dan jelas tentang konsep, uraian, data (bila ada), terdiri atas beberapa subjudul. Landasan teori ini digunakan sebagai pendukung hasil penelitian dan pembahasan.

\section{Metode Penelitian}

1. Desain Prosedur Perbaikan Pembelajaran

a) Desain

Perbaikan

\section{Pembelajaran}

Desain penelitian adalah semua proses penelitian yang diperlukan dalam proses perencanaan dan pelaksanaan penelitian dengan tujuan meminimalkan unsur kekeliruan.

Pelaksanaan perbaikan pembelajaran PPKn akan dilaksanakan dalam dua siklus, yaitu siklus 1 dan siklus 2 dengan sebelumnya telah dilaksanakan kegiatan pra siklus. Perbaikan pembelajaran ini menggunakan prosedur atau langkah yang dijabarkan menurut Sukidin, Basrowi, Suranto (2010:84).

Desain penelitian tindakan kelas dengan model siklus terdiri dari empat komponen yaitu rencana tindakan, tindakan yang akan dilakukan, observasi, dan refleksi. Selanjutnya melakukan pengamatan dan refleksi sebagai langkah keempat. Menurut IGAK. Wardhani dan Kuswaya Wihardit (2014:2.4) yaitu langkah merencanakan, kemudian melakukan tindakan sebagai langkah yang kedua merupakan realisasi dan rencana yang kita buat.

Langkah-langkah pada siklus 1 dan siklus 2 pada penelitian ini penulis menerangkan pada gambar bagan siklus 3.1.

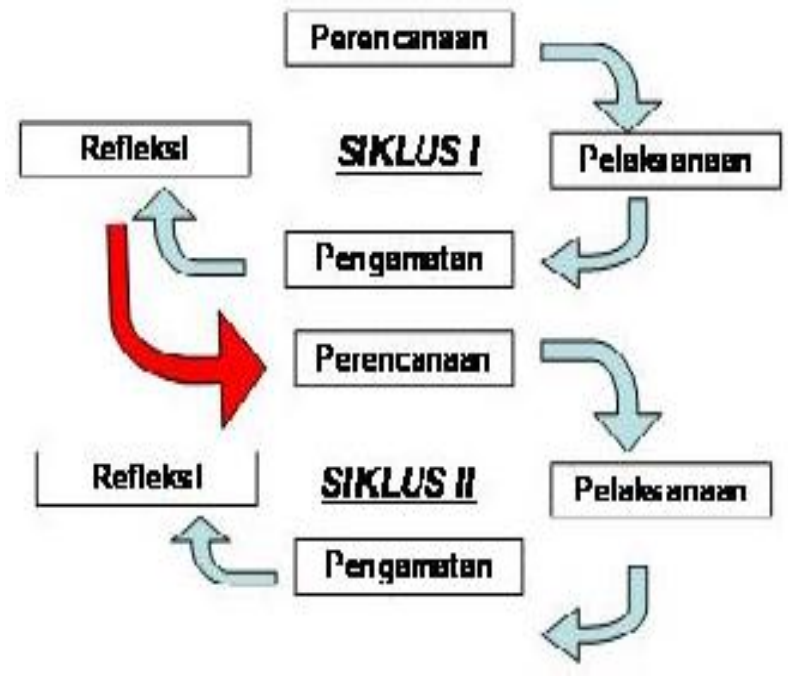

Gambar 3.1 Langkah PTK dalam Perbaikan Pembelajaran. 
2. Prosedur

Perbaikan

\section{Pembelajaran}

a. Siklus 1

1) Tahapan

Perencanaan

\section{Penelitian}

Pada tahap ini, persiapan yang dilakukan peneliti adalah menyiapkan materi makna persatuan dan kesatuan dalam keberagaman, menggunakan model pembelajaran picture and picture dengan langkahlangkah, membuat RPP yang sudah dipersiapkan oleh peneliti, membuat evaluasi dan berkoordinasi dengan teman sejawat atau orang-orang yang mengobserver tentang kegiatan pembelajaran yang akan dilaksanakan sebagai bentuk persiapan perencanaan untuk mencapai tujuan yang diharapkan.

Peneliti merencakan perbaikan pada model pembelajaran picture and picture sebagai model pembelajaran di kelas serta permasalahan yang dihadapi selama pembelajaran. Kemudian peneliti mensosialisasikan model pembelajaran picture and picture untuk membantu kesulitan siswa di kelas.

\section{2) Tahapan \\ Pelaksanaan Penelitian}

Pada tahap ini, di Siklus 1 akan dilaksanakan pada hari Kamis tanggal 20 Juli 2017. Langkahlangkah yang ditempuh dalam perbaikan pembelajaran siklus 1 adalah sebagai berikut:

$\checkmark$ Menyajikan materi sebagai pengantar yang menarik terhadap siswa.

$\checkmark$ Guru memperlihatkan atau menampilkan gambar-gambar yang berkaitan dengan materi makna persatuan dan kesatuan dalam keberagaman dan menjelaskan materi yang akan dibahas dan mendorong rasa ingin tahu serta menimbulkan pertanyaan dalam pikiran siswa.

Melalui pengamatan gambar, siswa disuruh menebak mana yang termasuk makna persatuan dan kesatuan dalam keberagaman secara bergantian dengan urutan yang logis.

$\checkmark$ Peneliti menanyakan alasan urutan dari gambar tersebut.

$\checkmark$ Dari alasan gambar tersebut guru mulai memberikan penguatan konsep yang sesuai dengan kompetensi yang ingin dicapai. 
Memberikan umpan balik positif dalam bentuk lisan maupun tulisan.

$\checkmark$ Membuat kesimpulan dari materi pembelajaran.

$\checkmark$ Memberikan soal sebagai bentuk evaluasi.

$\checkmark$ Memberikan tindak lanjut berupa PR.

\section{3) Tahapan Observasi}

Observasi atau pengamatan dilakukan oleh peneliti dan teman sejawat atau dua orang penilai/observer dengan mengamati penggunaan model pembelajaran Picture and Picture dengan hasil atau dampak dari tindakan-tindakan yang dilakukan siswa selama proses pembelajaran. Pengamatan tersebut dilaksanakan untuk memperoleh data tes dan data non tes siswa selama pembelajaran

berlangsung.

Observasi tes digunakan untuk mengetahui seberapa jauh peningkatan kemampuan siswa hasil tes yang telah diberikan.

\section{4) Tahapan Refleksi}

Peneliti bersama teman sejawat dan penilai/observer melakukan refleksi, dengan hasil refleksi yaitu peneliti menemukan kelemahan dan kelebihan dalam pelaksanaan pembelajaran siklus 1 , seperti gambar-gambar yang masih belum kumplit atau medianya masih kurang. Kelemahan dalam pelaksanaan pembelajaran akan diperbaiki pada siklus

\section{Hasil dan Pembahasan}

Berdasarkan hasil evaluasi pada materi makna persatuan dan kesatuan dalam keberagaman di kelas tinggi (IV), masih banyak siswa yang belum memahami konsep dalam pembelajaran PPKn. Untuk memperbaiki hal tersebut, peneliti melakukan Penelitian Tindakan Kelas dengan menerapkan model pembelajaran Picture and Picture yang di harapkan dapat memperbaiki dan meningkatkan hasil belajar siswa dalam pembelajaran PPKn materi makna persatuan dan kesatuan dalam keberagaman.

Agar proses pembelajaran berjalan lancar, maka peneliti menyusun rencana perbaikan pembelajaran (RPP) yang akan digunakan dalam setiap pertemuan.

\section{Pelaksanaan Siklus 1}

a. Perencanaan

Sebelum pelaksanaan siklus 1 peneliti menyusun rencana pembelajaran PPKn dengan materi makna persatuan dan kesatuan 
dalam keberagaman, melalui model pembelajaran Picture and Picture. Peneliti juga membuat lembar evaluasi berisi soal-soal sesuai dengan materi untuk mengetahui penerapan model pembelajaran Picture and Picture dalam pembelajaran PPKn, sedangkan lembar observasi merupakan lembar penilaian observer (pengamat) terhadap pelaksanaan pembelajaran mencakup pengamatan keterampilan guru. Peneliti menyiapkan media yang diperlukan dalam proses pembelajaran.

b. Pelaksanaan tindakan siklus 1

Pelaksanaan Siklus I, pada penelitian ini akan dilakukan pembelajaran PPKn dengan kompetensi dasar "Mengidentifikasi berbagai bentuk keberagaman suku bangsa, sosial dan budaya di Indonesia yang terikat Persatuan dan Kesatuan". Pada siklus 1 ini pembelajaran menggunakan model pembelajaran Picture and Picture. Hal tersebut dikarenakan pada saat tindakan pertama peneliti mengukur sejauh mana perbedaan efektifitas pembelajaran tanpa menggunakan model Picture and Picture.
Berdasarkan dari hasil

penilaian peserta didik pada pelaksanaan pra siklus kurang memuaskan maka peneliti melaksanakan perbaikan pembelajaran Siklus 1 dilaksanakan sesuai jadwal yang telah disepakati bersama, yakni pada tanggal, 15 September 2017 pada jam ke-2 pukul 07.35 - 08.10 WIB. Siswa yang mengikuti kegiatan pembelajaran sebanyak 30 orang. Jadi pada siklus 1 ini, proses pembelajaran diikuti oleh seluruh siswa. Materi yang dibahas pada siklus 1 ini "Makna Persatuan dan Kesatuan dalam Keberagaman". Pada penelitian ini dari segi aspek yang dianalisis adalah hasil belajar siswa, dan keaktifan siswa supaya bisa fokus dalam melaksanakan pembelajaran.

Pada Siklus 1, pembelajaran diawali dengan kegiatan berdoa yang dilakukan oleh seluruh siswa secara bersama-sama sesuai dengan peraturan sekolah yang berlaku. Selajutnya, guru mengawali pembelajaran dengan mengucakan salam dan membuka pelajaran dengan menginformasikan standar kompetensi, kompetensi dasar, dan tujuan pembelajaran yang ingin dicapai setelah siswa mengikuti 
kegiatan pembelajaran. Penelitian melakukan apersepsi dengan bertanya sejauh mana pengetahuan siswa mengenai materi yang akan disampaikan. Kegiatan pembelajaran pun berlangsung dan peneliti menjelaskan materi mengenai "makna persatuan dan kesatuan dalam keberagaman", dengan menggunakan model pembelajaran Picture and Picture.

Kegiatan ini berlangsung kurang lebih sekitar 35 menit dengan menggunkan model pembelajaran Picture and Picture kemudian peneliti menunjuk siswa ke depan untuk menempelkan atau mengurutkan gambar secara logis dan memberikan alasan mengenai gambar tersebut. Setelah selesai peneliti melakukan evaluasi dengan tes tertulis untuk mengukur sejauh mana pencapaian kompetensi belajar siswa menggunakan model pembelajaran Picture and Picture.

Berdasarkan temuan hasil penelitian dan refleksi pada materi makna persatuan dan kesatuan dalam keberagaman pada siklus 1 menunjukkan hasil yang lebih baik dibandingkan dengan pra siklus, terbukti keaktifan peserta didik lebih meningkat dan bisa fokus dalam belajar serta hasil evaluasinyapun meningkat walaupun masih ada sebagian peserta didik yang masih dibawah rata-rata kelas. Hal ini dapat dilihat dari lembar observasi berikut ini.

c. Hasil Belajar Siswa

Hasil belajar siklus 1 mata pelajaran PPKn siswa kelas tinggi (IV) melalui model pembelajaran Picture and Picture menunjukkan nilai sebagai berikut:

Tabel 4.1

Hasil Belajar Siklus 1

Rekap Nilai Siklus 1 kelas IV

Mata Pelajaran PPKn

\begin{tabular}{|r|r|l}
\hline \multicolumn{1}{|r|}{$\mathbf{N}$} & No. Induk & \\
\hline 1 & 141501001 & \\
\hline 2 & 141501002 & \\
\hline 3 & 141501003 & \\
\hline 4 & 141501004 & \\
\hline 5 & 141501005 & \\
\hline 6 & 141501006 & \\
\hline 7 & 141501007 & \\
\hline 8 & 141501009 & \\
\hline
\end{tabular}


Pendas : Jurnal IImiah Pendidikan Dasar, ISSN Cetak : 2477-2143 ISSN Online : 2548-6950

Volume III Nomor 1, Juni 2018

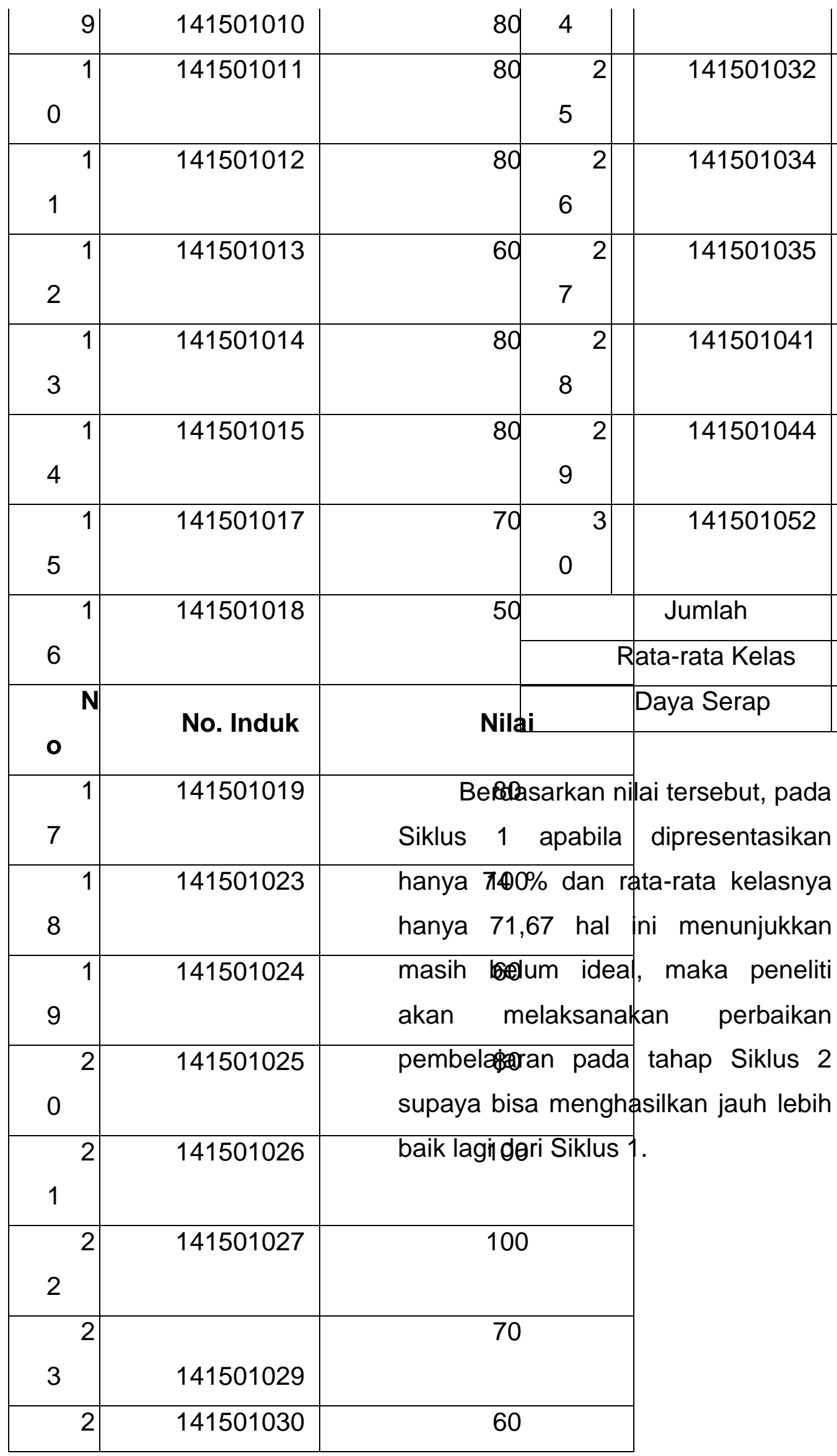




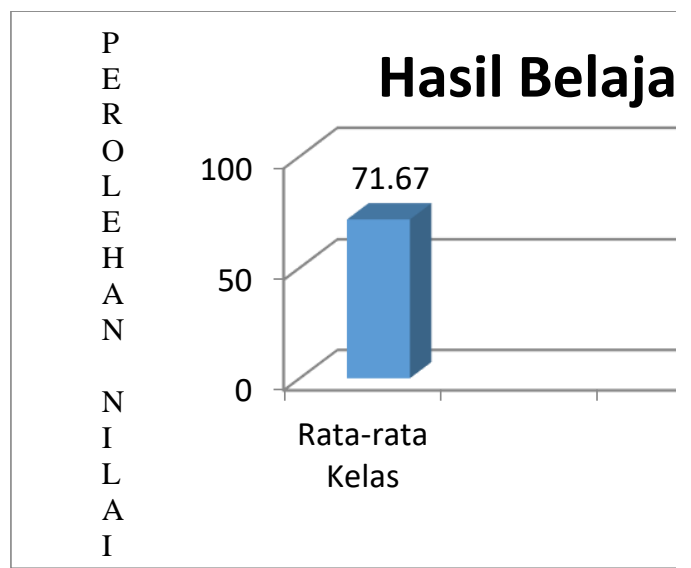

Diagram 4.1 Hasil Belajar Siklus

\section{Siklus 2}

\section{a. Perencanaan}

Berdasarkan hasil refleksi dan masalah pada siklus 1, kemudian peneliti melihat kembali efektivitas media gambar tentang makna persatuan dan kesatuan dalam keberagaman dan cara penyampaian yang efektif. Peneliti memeriksa dan menyiapkan rencana pembelajaran, lembar evaluasi, lembar observasi keterampilan guru untuk siklus 2, peneliti juga memeriksa kembali media dan prasarana yang diperlukan sebagai penunjang pembelajaran pelaksanaan siklus 2 .

b. Pelaksanaan Siklus 2

Berdasarkan hasil perbaikan pembelajaran pada Siklus 2 dilaksanakan sesuai jadwal yang telah disepakati bersama, yakni pada hari selasa, 22 September 2015 pada jam ke-2 pukul 07.35-08.10 Wib. Siswa yang mengikuti kegiatan pembelajaran sebanyak 30 orang. Jadi pada siklus 2 ini, proses pembelajaran diikuti oleh seluruh siswa. Materi yang dibahas pada siklus 2 ini adalah "makna persatuan dan kesatuan dalam keberagaman".

Pada materi yang dibahas masih menggunakan model pembelajaran Picture and Picture yang bertujuan untuk meningkatkan hasil belajar yang lebih baik lagi dan bisa belajar untuk fokus pada pembelajaran yang sedang berlangsung.

Berdasarkan hasil temuan pada siklus 2 dan refleksi yang membahas makna persatuan dan kesatuan dalam keberagaman menunjukkan hasil jauh lebih baik lagi dari siklus 1 , dan pada siklus 2 peserta didik jauh lebih fokus dan memahami materi yang sudah dilaksanakan. Hal tersebut bisa terbukti berdasarkan hasil evaluasi yang peserta didik jawab, dan hasilnya pun jauh lebih baik dari pra siklus maupun siklus 1 , apabila dipresentasikan hampir $90 \%$ yang mendapat nilai diatas 70 atau diatas rata-rata kelas. Hal ini bisa dilihat di tabel berikut ini. 
Pendas : Jurnal Ilmiah Pendidikan Dasar, ISSN Cetak : 2477-2143 ISSN Online : 2548-6950

Volume III Nomor 1, Juni 2018

Tabel 4.2

Hasil Belajar Siklus 2

Rekap Nilai Siklus 2 Kelas IV

Mata Pelajaran PPKn

\begin{tabular}{|c|c|c|c|}
\hline $\mathbf{N}$ & \multirow[t]{2}{*}{ No. Induk } & Nilai ${ }^{0}$ & \multirow{3}{*}{141501026} \\
\hline 0 & & & \\
\hline 1 & 141501001 & 801 & \\
\hline 2 & 141501002 & \begin{tabular}{|ll}
80 & 2
\end{tabular} & 141501027 \\
\hline 3 & 141501003 & 802 & \\
\hline 4 & 141501004 & $\begin{array}{ll}60 & 2\end{array}$ & \\
\hline 5 & 141501005 & 703 & 141501029 \\
\hline 6 & 141501006 & $80 \quad 2$ & 141501030 \\
\hline 7 & 141501007 & 804 & \\
\hline 8 & 141501009 & $\begin{array}{ll}80 & 2\end{array}$ & 141501032 \\
\hline 9 & 141501010 & 905 & \\
\hline 1 & 141501011 & $80 \quad 2$ & 141501034 \\
\hline 0 & & 6 & \\
\hline 1 & 141501012 & $\begin{array}{ll}90 & 2\end{array}$ & 141501035 \\
\hline 1 & & 7 & \\
\hline 1 & 141501013 & $\begin{array}{ll}60 & 2\end{array}$ & 141501041 \\
\hline 2 & & 8 & \\
\hline 1 & 141501014 & $\begin{array}{ll}90 & 2\end{array}$ & 141501044 \\
\hline 3 & & 9 & \\
\hline 1 & 141501015 & $\begin{array}{cc}80 & 3\end{array}$ & 141501052 \\
\hline 4 & & 0 & \\
\hline 1 & 141501017 & 90 & Jumlah \\
\hline 5 & & & a-rata Kelas \\
\hline 1 & 141501018 & 70 & aya Serap \\
\hline 6 & 141501018 & & \\
\hline 1 & 141501019 & Berdgoarkan & ekapan \\
\hline 7 & & tersebut, pada & us 2 apabila \\
\hline 1 & 141501023 & dipersentasgkan & a $90 \%$ dan \\
\hline
\end{tabular}


rata-rata kelas 83,67 hal ini menunjukkan adanya peningkatan yang signifikan setelah dilaksanakan perbaikan pembelajaran di siklus 2 .

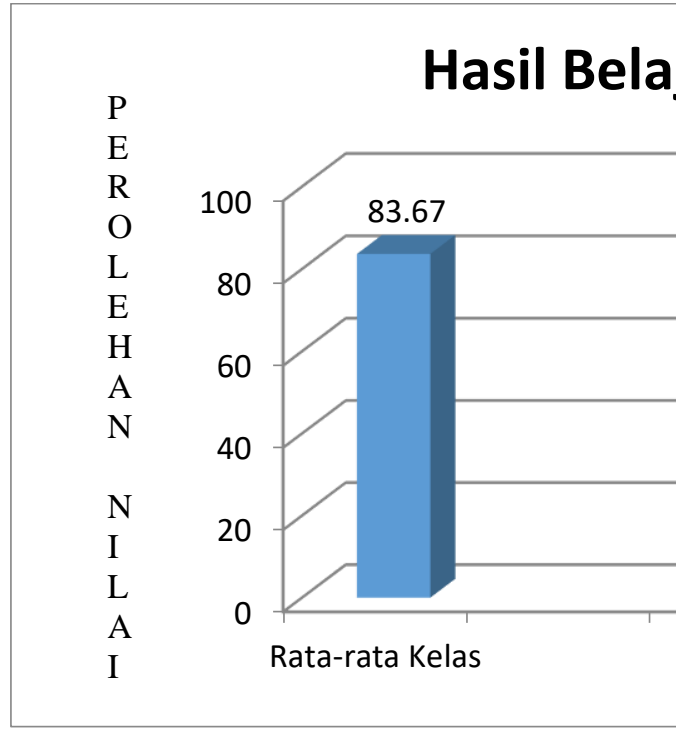

Diagram 4.2 Hasil Belajar Siklus

$$
2
$$

Pada test prasiklus nilai ratarata kelasnya hanya 67 , pada siklus 1 nilai rata-rata kelasnya 71,67 dan di siklus 2 nilai rata-rata kelasnya 83, 67. Hal tersebut mengalami peningkatan yang sangat tinggi. Data perbandingan hasil belajar siswa dapat di lihat pada tabel berikut ini.

Tabel 4.3

HASIL EVALUASI SISWA

KELAS IV SDN PAHLAWAN MATA

PELAJARAN PPKn PADA PRA

SIKLUS, SIKLUS 1 DAN SIKLUS 2

KKM : 70

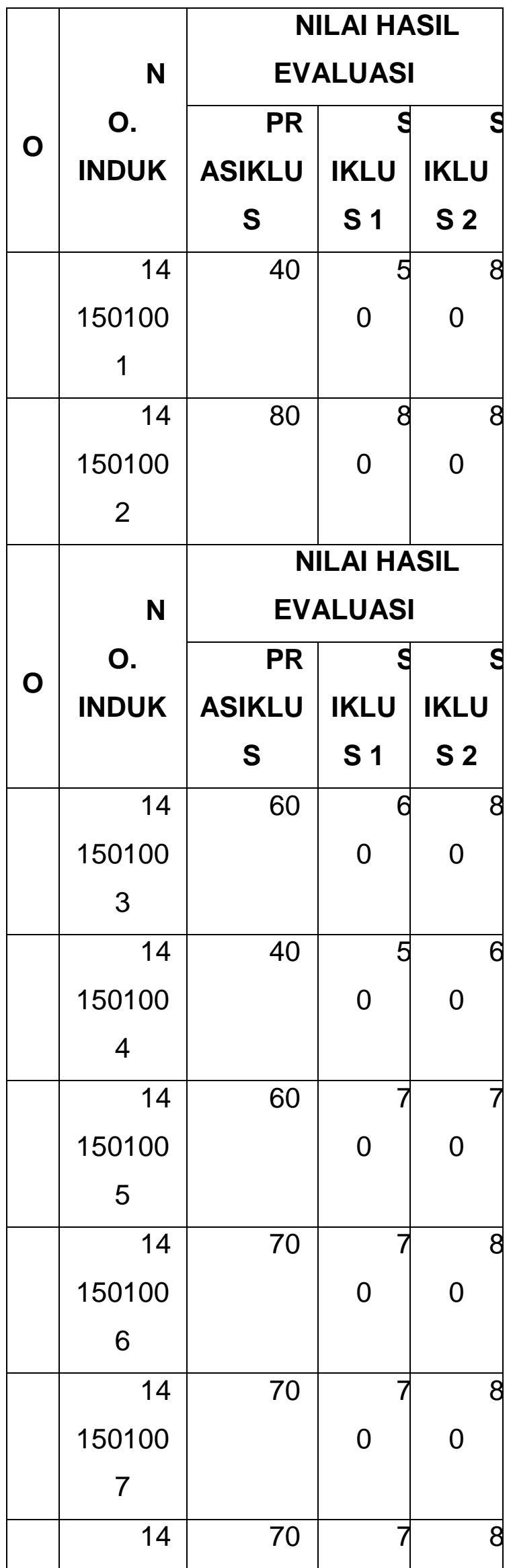


Pendas : Jurnal Ilmiah Pendidikan Dasar, ISSN Cetak : 2477-2143 ISSN Online : 2548-6950 Volume III Nomor 1, Juni 2018

\begin{tabular}{|c|c|c|c|c|c|c|c|c|c|}
\hline & 150100 & & 0 & 0 & & 14 & 60 & 6 & 9 \\
\hline & 9 & & & & 9 & 150102 & & 0 & 0 \\
\hline & 14 & 80 & & 9 & & 4 & & & \\
\hline & 150101 & & 0 & 0 & & 14 & 80 & 8 & 8 \\
\hline & 0 & & & & 0 & 150102 & & 0 & 0 \\
\hline & 14 & 80 & & 8 & & 5 & & & \\
\hline 0 & 150101 & & 0 & 0 & & 14 & 10 & 1 & 1 \\
\hline & 1 & & & & 1 & 150102 & 0 & 00 & 00 \\
\hline & 14 & 80 & & 9 & & 6 & & & \\
\hline 1 & 150101 & & 0 & 0 & & 14 & 10 & 1 & 1 \\
\hline & 2 & & & & 2 & 150102 & 0 & 00 & 00 \\
\hline & 14 & 50 & & 6 & & 7 & & & \\
\hline 2 & 150101 & & 0 & 0 & & 14 & 70 & 7 & 1 \\
\hline & 3 & & & & & 150102 & & 0 & 00 \\
\hline & 14 & 80 & & 9 & & 9 & & & \\
\hline 3 & 150101 & & 0 & 0 & & 14 & 40 & 6 & 6 \\
\hline & 4 & & & & 4 & 150103 & & 0 & 0 \\
\hline & 14 & 80 & & 8 & & 0 & & & \\
\hline 4 & 150101 & & 0 & 0 & & 14 & 40 & 5 & 8 \\
\hline & 5 & & & & 5 & 150103 & & 0 & 0 \\
\hline & 14 & 60 & & 9 & & 2 & & & \\
\hline 5 & 150101 & & 0 & 0 & & & 70 & 7 & 1 \\
\hline & 7 & & & & 6 & 150103 & & 0 & 00 \\
\hline & 14 & 40 & & 7 & & 4 & & & \\
\hline 6 & 150101 & & 0 & 0 & & & 50 & 7 & 1 \\
\hline & 8 & & & & 7 & 150103 & & 0 & 00 \\
\hline & 14 & 80 & & 8 & & 5 & & & \\
\hline 7 & 150101 & & 0 & 0 & & 14 & 70 & 7 & 1 \\
\hline & 9 & & & & 8 & 150104 & & 0 & 00 \\
\hline & 14 & 80 & & 9 & & 1 & & & \\
\hline 8 & 150102 & & 00 & 0 & & 14 & 60 & 7 & 8 \\
\hline & 3 & & & & 9 & 150104 & & 0 & 0 \\
\hline
\end{tabular}




\begin{tabular}{|c|c|c|c|c|}
\hline & 4 & & & \\
\hline \multirow{3}{*}{0} & 14 & 70 & 7 & 9 \\
\hline & 150105 & & 0 & 0 \\
\hline & 2 & & & \\
\hline & $\mathbf{J}$ & 2.0 & 2 & 2 \\
\hline & UMLAH & 10 & .150 & .510 \\
\hline & $\mathbf{R}$ & 67 & 7 & 8 \\
\hline & ATA- & & 1,67 & 3,67 \\
\hline & RATA & & & \\
\hline & NI & 10 & 1 & 1 \\
\hline & LAI & 0 & 00 & 00 \\
\hline & TERTIN & & & \\
\hline & GGI & & & \\
\hline & $\mathbf{N I}$ & 40 & 5 & 6 \\
\hline & LAI & & 0 & 0 \\
\hline & TEREN & & & \\
\hline & DAH & & & \\
\hline & & 60 & 7 & 9 \\
\hline & AYA & $\%$ & $4 \%$ & $0 \%$ \\
\hline & SERAP & & & \\
\hline
\end{tabular}

Tabel 4.4

Perbandingan Nilai Rata-rata Tiap Siklus

\begin{tabular}{|r|r|c|c|}
\hline o. & $\begin{array}{r}\text { Ha } \\
\text { sil }\end{array}$ & $\begin{array}{r}\text { Ju } \\
\text { mlah }\end{array}$ & $\begin{array}{r}\text { Nilai } \\
\text { Rata-rata } \\
\text { Kelas }\end{array}$ \\
\hline & $\begin{array}{r}\mathrm{Pr} \\
\text { a Siklus }\end{array}$ & $\begin{array}{c}2.0 \\
\mathrm{Si}\end{array}$ & 67 \\
\hline & 2.1 & 71,6 \\
klus 1 & 50 & 7 \\
\hline & $\mathrm{Si}$ & 2.5 & 83,6 \\
\hline
\end{tabular}

\begin{tabular}{|l|l|l|l|}
\hline & klus 2 & 10 & 7 \\
\hline
\end{tabular}

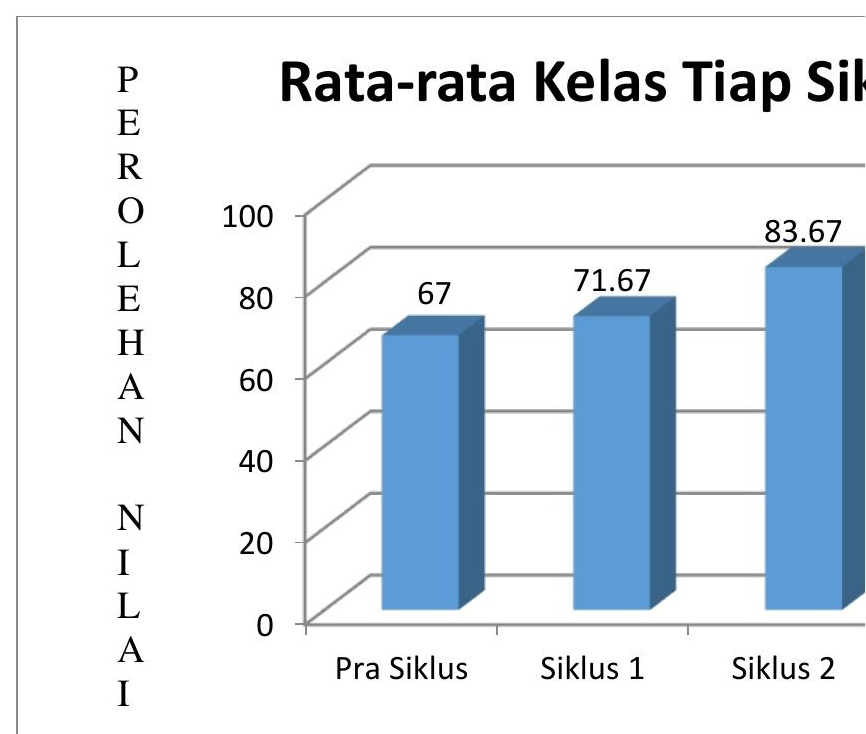

Diagram 4.3 Hasil Belajar Siswa Tiap Siklus

\section{A. Pembahasan Hasil}

\section{Penelitian Perbaikan Pembelajaran}

Penggunaan model pembelajaran Picture and Picture dalam meningkatkan hasil belajar siswa pada pokok bahasan makna persatuan dan kesatuan dalam keberagaman. Diawali dengan pemberian test awal atau sering disebut sebagai kegiatan pra siklus pada pokok bahasan makna persatuan dan kesatuan dalam keberagaman, yang diperoleh peserta didik hanya memperoleh rata-rata kelas 67 . Kegiatan tersebut dimaksudkan untuk mengetahui kemampuan awal siswa mengenai 
makna persatuan dan kesatuan dalam keberagaman sebelum menggunakan model pembelajaran Picture and Picture selanjutnya dilaksanakan siklus 1 untuk mengetahui perkembangan hasil belajar peserta didik.

Selain itu, dalam model pembelajaran Picture and Picture hasil test awal berguna sebagai acuan dan bahan pertimbangan untuk mengetahui nilai perkembangan siswa pada pembelajaran berikutnya. Setelah pemberian test awal selanjutnya siswa diberikan pembelajaran dengan materi yang sama dengan pra siklus dengan menggunakan model pembelajaran Picture and Picture tahap pertama atau siklus 1 yang diperoleh hanya memperoleh ratarata kelas 71,67 yang bila dipersentasikan $74 \%$ yang diatas rata-rata kelas, tetapi belum memperoleh hasil yang ideal, berlanjut dengan tahap kedua atau siklus 2.

Setelah peneliti melakukan analisis antara siklus 1, dan siklus 2, siswa mengalami berbagai perubahan sikap ke arah yang lebih baik. Pengalaman yang diperoleh siswa pada pembelajaran siklus I memberi banyak perubahan terutama bisa lebih fokus pada pembelajaran dan lebih aktif untuk ke depan. Hal tersebut sesuai dengan salah satu tujuan penting dari model pembelajaran Picture and Picture yaitu untuk pengembangan keterampilan yang bertujuan untuk mengembangkan keterampilan sosial siswa.

Berdasarkan hasil evaluasi siklus 2, yang diperoleh peserta didik sudah mencapai rata-rata kelas 83,67 dan bila dipersentasikan $90 \%$ yang diatas rata-rata kelas. Oleh karena itu dapat peneliti simpulkan pada dasarnya siswa senang dalam mengikuti pembelajaran menggunakan metode Picture and Picture. Kesulitan yang siswa rasakan lebih pada waktu yang sangat terbatas karena metode ini sesungguhnya membutuhkan waktu yang panjang dalam pelaksanaannya. Kesulitan yang siswa rasakan juga yaitu ketika mereka harus memilih gambar yang akan diurutkan dan menyampaikan alasan mengenai urutan gambar tersebut. Siswa juga merasa lebih paham dengan pembelajaran menggunakan model Picture and Picture karena model ini melatih 
siswa

dalam

mengurutkan, memasangkan gambar dan menyampaikan alasan terhadap gambar yang di urutkannya itu.

Dengan pembelajaran tersebut siswa merasa mendapat pengalaman baru dengan diterapkannya pembelajaran Picture and Picture. Meskipun begitu, siswa merasa model pembelajaran Picture and Picture sangat bermanfaat bagi siswa dalam proses pembelajarannya karena sangat membantu memahami materi pembelajaran, terutama pada pelajaran PPKn yang membahas mengenai makna persatuan dan kesatuan dalam keberagaman.

\section{E. Kesimpulan}

Berdasarkan hasil penelitian yang diperoleh, melalui perbaikan pembelajaran dari pra siklus, siklus 1 dan siklus 2, peneliti dapat menarik kesimpulan yang dapat dipaparkan berikut ini.

1. Peningkatan hasil belajar siswa dengan menggunakan model pembelajaran Picture and Picture pada pembelajaran PPKn dalam materi makna persatuan dan kesatuan dalam keberagaman siswa kelas tinggi (IV) SDN Pahlawan Kecamatan Banjaran
Kabupaten Bandung. Dapat di lihat dari hasil penilaian pra siklus nilai rataa-rataa kelas sebesar 67 , siklus 1 nilai rata-rata kelas sebesar 71,67, dan siklus 2 nilai rata-rata kelas sebesar 83,67. Melalui pembelajaran Picture and Picture pada mata pelajaran PPKn dapat meningkatkan hasil belajar siswa.

Berdasarkan simpulan diatas, saran yang mudah-mudahan dapat menjadi bahan masukan dalam melaksanakan proses belajar mengajar adalah sebagai berikut: Sekolah sebaiknya meningkatkan ketersediaan sarana atau media pembelajaran yang mendukung pelaksanaan model pembelajaran Picture and Picture dan sekolah sebaiknya mengadakan kegiatankegiatan pelatihan bagi guru di sekolah khususnya berkaitan dengan model pembelajaran Picture and Picture. Guru sebaiknya dapat terus mengembangkan dan menerapkan model pembelajaran Picture and Picture terutama untuk pembelajaran materi-materi PPKn pada pokok bahasan makna persatuan dan kesatuan dalam keberagaman dalam meningkatkan hasil belajar siswa. 
1. Siswa hendaknya lebih memperhatikan saat guru menjelaskan langkah-langkah model pembelajaran Picture and Picture sehingga dapat diterapkan dengan baik dalam kegiatan pembelajaran.

2. Mengingat keterbatasan waktu dalam penelitian ini, diharapkan peneliti dapat memperoleh manfaat setelah menggunakan model pembelajaran Picture and Picture pada mata pelajaran PPKn.

\section{DAFTAR PUSTAKA}

Arsyad, Azhar M.A. (2007). Media Pembelajaran, Jakarta: PT Raja Grafindo Persada.

Atha Anak Cerdas. (2011/2012). Hakekat Fungsi dan Tujuan PKn di SD. Blogspot.com.

Zamroni. (2005:7). Pengertian PKn. Tim ICCE.

Depdiknas. (2006:49). Pengertian Pendidikan Kewarganegaraan. Somantri. (2001:154). Pengertian Pendidikan Kewarganegaraan.

Azis Wahab. (Cholisin, 2000:18). Pengertian Pendidikan Kewarganegaraan.

Aqib, Zaenal. (2013). Model-model, Media, dan Strategi
Pembelajaran Kontekstual Inovatif. Bandung : Yrama Widya.

Ihsan, Fuad. (2008). Dasar-dasar Kependidikan. Jakarta : Rineka Cipta. Istarani, (2011).Model Pembelajaran Inovatif (Referensi Guru Dalam Menentukan Model Pembelajaran), Medan : Media Persada.

Makmum Syamsuddin Abin. (2005). Psikologi Pendidikan.Bandung : PT Remaja Rosdakarya Mudjiono \& Dimyati. (2006). Belajar dan Pembelajaran. Jakarta : PT. Rineka Cipta.

Sudjana Nana \& Ahmad Rivai. (2001). Media Pembelajaran, Bandung: Sinar Baru Algensindo.

Sudjana Nana. (2012). Penilian Hasil Proses Belajar Mengajar, Bandung: PT Remaja Rosdakarya.

Syaiful sagala. (2005). Landasan

Pendidikan. Bandung:

Percikan IImu.

Taniredja Tukiran, dkk. (2012). Model-Model Pembelajaran Inovatif. Bandung: Alfabeta.

Uno B Hamzah. (2006). Perencanaan Pembelajaran. Jakarta : PT Bumi Aksara 
Uno, (2007). Model Pembelajaran Menciptakan Proses Belajar

Mengajar Yang Kreatif dan

Efektif. Jakarta : PT Bumi

Aksara.

Wardhani, IGAK dan Kuswaya

Wihardit. (2014). Penelitian

Tindakan Kelas. Tangerang

Selatan: Universitas Terbuka. 